\title{
PAKOM PELATIHAN PENGOPERASIAN KOMPUTER BAGI PERANGKAT DESA DI KECAMATAN GONDANGREJO KABUPATEN KARANGANYAR
}

\author{
Hernawan Sulistyanto \\ Program Studi Pendidikan Teknik Infomatika \\ Fak. Keguruan dan Ilmu Pendidikan \\ Universitas Muhammadiyah Surakarta \\ J1. A. Yani Tromol Pos 1 Pabelan, Surakarta \\ E-mail: Hernawan.Sulistyanto@ums.ac.id
}

\begin{abstract}
ABSTRAK
Kegiatan pengabdian pada masyarakat ini bertujuan untuk memberikan motivasi, pengetahuan dan ketrampilan/keahlian dasar dalam penguasaan teknologi komputer dan informasi guna meningkatkan skill dan kompetensi perangkat desa dalam dunia kerja melayani masyarakat. Khalayak sasaran pengabdian adalah golongan usia produktif, yaitu para perangkat desa di Desa Tuban Kecamaatan Gondangrejo Kabupaten Karanganyar Jawa Tengah. Kegiatan pengabdian yang berbentuk pelatihan ini dilakukan dengan metode ceramah, demonstrasi, latihan, dan tanya-jawab. Metode ceramah digunakan untuk mengaktivasi semangat guna meningkatkan motivasi belajar para perangkat sekaligus digunakan untuk menjelaskan konsep teknologi komputer. Metode demonstrasi dipakai untuk menunjukkan suatu proses kerja dan pembelajaran, yaitu tahap-tahap pengoperasian komputer termasuk diantaranya cara pengoperasian Windows dan Microsoft Office. Sementara itu, metode latihan digunakan untuk mempraktekkan cara merakit mrngoperasikan beberapa aplikasi yang akan dipelajari. Sedangkan metode tanya-jawab memberikan kesempatan pada para peserta untuk berkonsultasi dalam mengatasi kendala-kendala yang muncul selama instalasi proses pelatihan dan pembelajaran program-program komputer.

Berdasarkan kegiatan yang telah dilaksanakan maka dapat diambil kesimpulan bahwa hampir seluruh peserta pelatihan sangat antusias dalam mengikuti pelatihan komputer yang diadakan dengan diindikasikan para perangkat desa setelah pelatihan berakhir mampu memahami dan mempraktekan dengan baik seluruh materi yang disampaikan selama kegiatan pengabdian. Sebuah kendala yang muncul adalah keterbatasan alat peraga dan praktek yaitu perangkat komputer yang terbatas sehigga mengakibatkan pelaksanaan kegiatan belum bisa berjalan maksimal.
\end{abstract}

Kata Kunci: perangkat desa, teknologi komputer, Windows

\section{PENDAHULUAN}

Globalisasi memberikan akses kemudahan bagi pengalihan beragam teknologi di banyak bidang kehidupan di berbagai negara (Ellis, 1999). Khususnya di Indonesia, teknologi komputer merupakan salah satu bidang yang paling dirasakan perkembangannya sampai saat ini. Faktor terpenting guna pengimplementasian teknologi komputer ini adalah sumber daya manusia sebagai pengguna sekaligus operator dari sistem berbasis komputer tersebut. Keahlian dalam penggunaan komputer saat ini menjadi sebuah syarat mutlak bagi hampir setiap pelaksana dan pelaku pendidikan, perkantoran, dan industri (Esmara, 2005 \& Kempton, 2009).

Salah satu elemen yang paling potensial untuk mengoptimalkan penggunaan sistem komputer di banyak bidang adalah unsur 
perangkat desa yang mana sebagai sumber daya manusia golongan usia produktif yang berperan sebagai pelayan masyarakat.

Pengembangan wilayah berbasis sumber daya manusia (SDM) adalah pendekatan yang harus dilaksanakan untuk membangun daerah yang kuat secara sosial dan ekonomi. Sumber daya manusia antar wilayah sangatlah berbeda-beda. Permasalahn yang begitu beragam dan kompleks membutuhkan peran serta semua pihak untuk menguraikan masalah itu dan menemukan solusinya.

Masa sekarang ini pemerintahan desa dihadapkan pada banyak tantangan dan hambatan akibat dari perkembangan dinamika masyarakat yang semakin kritis dan berwawasan maju. Jumlah warga yang semakin bertambah banyak dengan beragam latar belakang pendidikan, status sosial, dan profesi menjadikan bentuk layanan pemerintahanan di desa akan semakin komplek. Dalam hal ini pemeritahan desa sebagai barisan terdepan pada pemerintahan Negara Indonesia dalam pelayanan kepada masyarakat dituntut untuk mempunyai kinerja yang prima.

Namun sayangnya pada kenyataannya saat ini model serta kualitas layanan yang disajikan oleh kebanyakan pemerintahan desa masih jauh dari harapan yang diidamkan oleh warganya, diantaranya ialah lambannya proses penanganan administratif desa. Hasil identifikasi terhadap penyebab munculnya permasalahan ini adalah ditemukannya sebagian besar personal perangkat desa belum mampu menggunakan perangkat komputer dengan baik dan selayaknya. Kurangnya kemahiran penguasaan teknologi komputer dari perangkat desa tidak terlepas dari latar belakang pendidikan yang dimiliki oleh personal perangkat desa yang mana kabanyakan hanya lulusan sekolah kejuruan dan sekolah menegah atas. Keterbatasan ini tentunya dapat langsung dirasakan oleh masyarakat oleh karena saat ini alat utama yang digunakan dalam mendukung pelayanan kepada warga menggunakan komputer.

Adanya peningkatan kemampuan secara kualifikatif perangkat desa sebagai SDM pemerintahan di desa secara signifikan akan menjembatani pencapaian keberhasilan jalannya kesinambungan pembangunan di desa melalui pemberian layanan yang baik bagi warga.

Berdasarkan data demografi kependudukan Desa Tuban dan Selokaton Kabupaten Karanganyar antara tahun 2009 sampai dengan 2016 menunjukkan bahwa masih sedikit jumlah kalangan perangkat desa yang memahami dan menguasai teknologi berbasiskan komputer (NN, 2016). Akibat yang ditimbulkan oleh kondisi seperti ini adalah pelayanan masyarakat masih banyak menggunakan cara manual (paper based). Adanya kenyataan seperti ini tentunya akan sulit bagi perangkat desa secara khusus dan bagi desa secara umum untuk mengikuti perkembangan kemajuan misalkan perekonomian pada sektor-sektor usaha yang saat ini utamanya justru banyak disokong oleh penggunaan teknologi komputer (Moeljanto, 2008).

Pemilihan Kecamatan Gondangrejo sebagai wilayah PAKOM yang akan difokuskan pada permasalahan SDM dalam hal ini perangkat desa dikarenakan :

1. Memiliki jumlah penduduk yang tergolong besar dalam wilayah Kabupaten Karanganyar.

2. Memiliki potensi perindustrian yang besar dengan banyaknya jumlah industri besar berskala nasional yang berada diwilayah Kecamatan Gondangrejo, yaitu pabrik rokok Menara, pabrik rokok Gudang Garam, pabrik tekstil Mutu Gading, pabrik rokok Kerbau serta pusat industri meubel Roda Jati. Adanya ini akan memicu munculnya tuntutan layanan yang prima dari pemerintahan desa.

3. Memiliki beberapa tempat pusat keramaian publik, seperti pasar induk Tuban, terminal besar Gondangrejo, dan dekat dengan bandara Adi Sumarmo.

Tantangan yang dihadapi pemerintahan desa di semua bidang cukuplah kompleks sehingga dibutuhkan kompetensi dan 
profesionalisme agar dapat menyediakan layanan terbaik bagi masyarakat. Maka pilihan bidang peningkatan sumber daya manusia (SDM) diharapkan akan merupakan salah satu solusi yang baik untuk menyelesaikan dan menangani permasalahan yang sedang muncul tersebut.

Lokasi kegiatan ditetapkan di Desa Tuban didasarkan pada:

1. Populasi dan kepadatan penduduk di desa tersebut paling tinggi diantara desa lainnya di Kecamatan Gondangrejo.

2. Permintaan dari Kepala Desa serta tokoh-tokoh masyarakat setempat.

Kedua wilayah tersebut letaknya strategis di jalur pertumbuhan ekonomi antara Kodya Surakarta, Kabupaten Boyolali, dan Kabupaten Sragen. Terlebih di sektar Desa Tuban terdapat beberapa industri besar, sekolahan dari SD, SMP/MTS sampai SMU/ MAN, dan pusat-pusat bisnis/perekonomian serta berlokasinya ibu kota Kecamatan Gondangrejo.

Kecamatan Gondangrejo merupakan salah satu dari 17 kecamatan di wilayah Kabupaten Karanganyar bagian utara sebelah barat dengan keadaan topografi ketinggian $\pm 117 \mathrm{M} \mathrm{dpl}$, bersuhu $29^{\circ} \mathrm{C}$, tergolong dataran rendah. Jarak bentang wilayahnya sekitar $22 \mathrm{Km}$ dari Utara ke Selatan dan membentang sekitar $18 \mathrm{Km}$ dari Timur ke Barat. Sementara itu, Desa Tuban merupakan desa yang berada disisi utara dan Desa Selokaton berada di sisi selatan dari wilayah Kecamatan Gondangrejo. Secara administratif, Kecamatan Gondangrejo berbatasan dengan:

1. Kecamatan Gemolong wilayah Kabupaten Sragen di sebelah utara;

2. Kecamatan Ngemplak wilayah Kabupaten Boyolali di sebelah barat;

3. Kecamatan Nusukan wilayah Kodya Surakarta di sebelah selatan; dan

4. Kecamatan Kebak Kramat wilayah Kabupaaten Sragen di sebelah timur.

Posisi geografis wilayah Kecamatan Gondangrejo terutama Desa Tuban dan
Desa Selokaton merupakan kekuatan yang dapat menopang pembangunan di wilayah sekitarnya.

Desa Tuban dan Desa Selokaton merupakan bagian dari 13 desa yang terdapat di wilayah Kec. Gondangrejo, Kab. Karanganyar dimana pemanfaatan lahan mayoritas untuk pertanian. Secara umum, gambaran geografis dan demografis disajikan pada Tabel 1 di bawah ini.

Tabel 1. Gambaran demografis desa

\begin{tabular}{|c|c|c|c|}
\hline No & Komponen & $\begin{array}{l}\text { Desa } \\
\text { Tuban }\end{array}$ & $\begin{array}{c}\text { Desa } \\
\text { Selokaton }\end{array}$ \\
\hline 1 & Luas wilayah & $\begin{array}{c}278,3025 \\
\text { На }\end{array}$ & $\begin{array}{c}225,4635 \\
\text { На }\end{array}$ \\
\hline 2 & Jumlah penduduk & 6996 & 5344 \\
\hline 3 & $\begin{array}{l}\text { Pendidikan } \\
\text { penduduk dibawah } \\
\text { SMA }\end{array}$ & $\begin{array}{c}6404 \\
(91 \%)\end{array}$ & $\begin{array}{c}5102 \\
(95 \%)\end{array}$ \\
\hline 4 & $\begin{array}{l}\text { Pekerjaan } \\
\text { berhubungan TIK }\end{array}$ & $26 \%$ & $19 \%$ \\
\hline 5 & $\begin{array}{l}\text { Latar belakang } \\
\text { pendidikan } \\
\text { perangkat desa } \\
\text { setara SMA/SMK }\end{array}$ & $100 \%$ & $100 \%$ \\
\hline 6 & $\begin{array}{l}\text { Kemampuan } \\
\text { perangkat desa } \\
\text { mengoperasikan } \\
\text { komputer dan } \\
\text { aplikasi perkantoran } \\
\text { dengan semestinya } \\
\text { dan sesuai } \\
\text { utilitasnya }\end{array}$ & $10 \%$ & $20 \%$ \\
\hline
\end{tabular}

TUJUAN DAN MANFAAT KEGIATAN

Berdasarkan pada analisa situasi di atas maka dapat dijustifikasi beberapa permasalahan prioritas yang terkait dengan sumber daya manusia (SDM) khususnya perangkat desa, yaitu:

- Lemahnya pengetahuan dan pemahaman perangkat desa pada teknologi informasi dan komputer.

- Terbatasnya kemampuan perangkat desa dalam mengoperasikan perangkat koomputer baik secara perangkat keras maupun perangkat lunak. 
- Kurangnya kemampuan dan keahlian perangkat desa dalam menggunakan program aplikasi perkantoran.

- Rendahnya kualifikasi pendidikan perangkat desa.

Berangkat dari permasalahan mitra di atas maka dapat dirumuskan suatu permasalahan umum, yaitu bagaimana meningkatkan kemampuan dan ketrampilan perangkat desa dalam menguasai teknologi komputer terutama keahlian pengoperasian kompter dan program aplikasi perkantoran sehingga akan mempunyai kompetensi dan ketrampilan yang memadai dalam memberikan pelayanan kepada masyarakat umumnya dan dalam menjalankan tugas administrasi pemerintahan desa khususnya. Tujuan kegiatan pengabdian ini adalah: (1) Memperkenalkan teknologi perangkat komputer bagi perangkat desa melalui pelatihan pengoperasian komputer personal.

(2) Memberikan pelatihan pengoperasian program dan aplikasi perkantoran bagi perangkat desa.

Sementara itu manfaat kegiatan pengabdian ini yaitu: (1) Meningkatkan kemampuan dan ketrampilan perangkat desa dalam mengoperasiikan komputer melalui pelatihan penggunaan sistem operasi Windows dan Aplikasi Microsoft Office; (2) Membekali perangkat desa agar memiliki keahlian dasar dalam teknologi komputer guna meningkatkan layanan yang lebih baik pada masyarakat dan dalam menjalankan tugas rutin administrasi.

\section{METODE PELAKSANAAN KEGIATAN}

Berdasarkan permasalahan yang ada maka selanjutnya dikerjakan beberapa tahapan yang menjadi solusi bagi masalah tersebut. Program PAKOM ini mengunakan metode RRA (Rapid Rural Appresial)./PRA (Partisipatori Rural Appresial)/ RRA dan PRA adalah falsafah, pendekatan metode yang dikenal sebagai Memahami Desa Secara Cepat. Adapun prinsip-prinnsip RRA dan PRA yang dipakai dalam kegiatan ini adalah :
- Belajar Secara Cepat dan Progresif, melalui eksplorasi yang terencana, pemakaian metode yang fleksibel, improvisasi, pengulangan serta menyesuaikan dengan proses belajar atau pemahaman.

- Optimalisasi Pertukaran, mengaitkan biaya pemahaman dengan informasi yang benar-benar bermanfaat bagi Desa Tuban, Kec. Gondangrejo, Kab. Karanganyar dengan pertukaran antar kuantitas, kegayutan, keakuratan serta ketepatan waktu .

- Pemberian fasilitas, artinya memberikan fasilitas penyelidikan, analisis, penyajian dan pemahaman oleh masyarakat di wilayah Desa Tuban, Kec. Gondangrejo, Kab. Karanganyar sehingga mereka dapat menyajikan dan memiliki hasilnya, dan juga mempelajarinya.

- Kesadaran dan tanggung jawab diri yang kritis, artinya fasilitator secara terus-menerus menguji tingkah laku mereka dan mencoba melakukannya secara lebih baik.

- Saling berbagi informasi dan gagasan antar masyarakat di Desa Tuban, Kec. Gondangrejo, Kab. Karanganyar dengan fasilitator, dan antar fasilitator yang berbeda, serta saling berbagi wilayah kegiatan, pelatihan dan pengalaman antar organisasi yang berbeda.

Kegiatan - kegiatan diatas dilakukan dengan Focus Group Discussion (FGD), pelatihan, pendampingan dan diakhiri dengan evaluasi dan monitoring. Tahapan solusi dikemas dalam bentuk kegiatan sebagaimana disajikan pada Tabel 3 berikut ini.

Tabel 3. Skedul waktu pelaksanaan

\begin{tabular}{llcl}
\hline No & $\begin{array}{c}\text { Program } \\
\text { kegiatan }\end{array}$ & $\begin{array}{c}\text { Bulan } \\
\text { ke- }\end{array}$ & Metode \\
\hline 1. & $\begin{array}{l}\text { Persiapan dan } \\
\text { koordinasi, } \\
\text { penyebaran } \\
\text { undangan }\end{array}$ & 1 & Diskusi \\
2 & Pengetahuan TIK & 2 & Ceramah-diskusi
\end{tabular}


3 Penggunanaan

\begin{tabular}{lcl}
$\begin{array}{l}\text { Komputer } \\
\text { dan aplikasi } \\
\text { perkantoran }\end{array}$ & 2 & $\begin{array}{l}\text { Praktek- } \\
\text { pendampingan }\end{array}$ \\
$\begin{array}{l}\text { Instalasi } \\
\text { Windows dan }\end{array}$ & 3 & $\begin{array}{l}\text { Praktek- } \\
\text { pendampingan }\end{array}$ \\
$\begin{array}{l}\text { MS Office } \\
\text { Praktek } \\
\text { penggunaan }\end{array}$ & 3 & $\begin{array}{l}\text { Praktek- } \\
\text { pendampingan }\end{array}$ \\
\hline
\end{tabular}

Guna mengatasi permasalahan sebagaimana telah dipaparkan pada bagian sebelumnya maka dapat ditempuh beberapa alternative solusi, yaitu pertama menjelaskan pengetahuan dasar mengenai pengertian, bagian-bagian serta fungsi dari komputer dan sistem operasi. Kedua adalah memberikan pelatihan cara mengoperasikan sistem komputer dengan sistem operasinya dan aplikasi lainnya. Metode yang dilaksanakan untuk mencapai tujuan yang telah ditetapkan dan dengan mengacu pada kerangka pemecahan masalah adalah sebagai berikut: (1) Berkomunikasi dengan Kepala Desa Tuban guna mendiskusikan rencana kegiatan pengabdian dan mendata para calon peserta yang akan mengikuti pelatihan dalam kegiatan ini. (2) Melaksanakan pelatihan dengan sesi-sesi materi yaitu:

a. Pengantar pengetahuan tentang perangkat keras komputer, bagianbagiannya dan fungsinya.

b. Perakitan perangkat keras komputer menjadi sebuah komputer personal.

c. Materi pengetahuan mengenai sistem operasi dan fungsinya.

d. Penggunaan sistem operasi yang telah diinstal pada sistem komputer sesuai dengan Nutt (2000) dan Stallings (2001).

e. Pengoperasian aplikasi Microsoft Office lengkap, diantaranya Ms Word, Ms Power Point, dan Ms Excel sesuai dengan Solomon \& Russinovitch (2000).

Keberhasilan kegiatan pengabdian pada masyarakat ini dievaluasi dengan beberapa indikator, yaitu:

a. $80 \%$ minimal peserta selalu rutin hadir dalam pelatihan b. $75 \%$ dari peserta pelatihan mampu untuk mempraktekkan seluruh materi pelatihan

c. $30 \%$ peserta pelatihan mempunyai inisiatif untuk mengembangkan kemampuan penguasaan pada perangkat lunak yang lain dalam sistem komputer

d. Pernyataan kepuasan dari para peserta pelatihan serta pemerintah desa setempat

\section{HASIL DAN PEMBAHASAN PELAKSANAAN KEGIATAN}

Berdasarkan permasalahan yang dihadapi oleh mitra sebagaimana diungkapkan dalam bagian sebelumnya di depan maka kegiatan pengabdian masyarakat telah dilaksanakan dengan suatu alternatif solusi melalui pendekatan individual dan klasikal. Pendekatan klasikal dilaksanakan pada saat pemberian dan penyampaian materi mengenai pengetahuan umum komputer dan aplikasinya. Sedangkan pendekatan individual dilakukan pada saat latihan dan tanya-jawab.

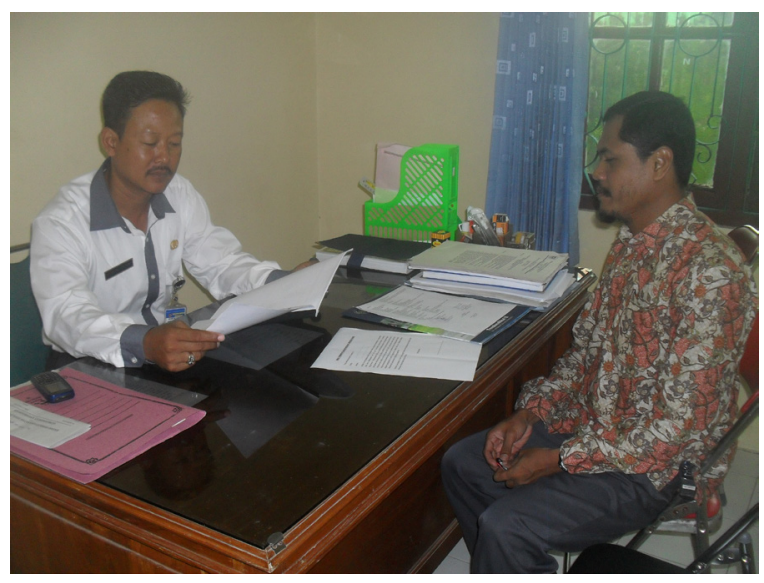

Gambar 1. Kepala Desa Tuban mendiskusikan pelaksanaan kegiatan dengan ketua pelaksana PAKOM

Adapun metode yang digunakan selengkapnya dipaparkan sebagai berikut.

a. Ceramah

Metode ini dipilih untuk menyampaikan konsep-konsep penting yang harus dimengerti dan dikuasai oleh peserta pelatihan. Penggunaan metode ini dengan pertimbangan bahwa metode 
ceramah yang dikombinasikan dengan gambar-gambar, animasi dan display dapat memberikan materi yang relative banyak secara padat, cepat dan mudah. Metode ini juga digunakan dalam pemotivasian para peserta secara psikologis.

b. Demonstrasi

Metodeinidigunakanuntukmenunjukkan suatu proses kerja yaitu tahap-tahap instalasi komputer serta windows dan aplikasi perkantoran. Demonstrasi dilaksanakan dan diperagakan oleh instruktur dihadapan para peserta secara langsung sehingga masing-masing peserta dapat mengamati secara jelas cara-cara melakukan perakitan instalasi komputer dan pengoperasian windows, serta aplikasi lainnya.

c. Latihan

Metode latihan ini digunakan untuk memberikan tugas mandiri kepada para peserta untuk mempraktekan instalasi komputer dan pengoperasian Windows dan aplikasi perkantoran.

d. Tanya-jawab

Metode ini dilakukan untuk menjaga pendekatan individual dengan para peserta baik secara teknis maupun psikologis.

Khalayak sasaran yang strategis dalam kegiatan ini adalah masyarakat pelaksanan administrasi di kantor kepala desa. Jumlah peserta pelatihan ditargetkan sebanyak 15 orang yang terdiri atas seluruh jajaran perangkat desa baik pria dan wanita, namun dalam pelaksanaan kegiatan ini hanya berkisar 5 sampai 8 orang yang selalu aktif dikarenakan banyak faktor kesibukan lain yang harus dijalankan oleh para perangkat desa.

Materi yang disajikan dalam pelatihan ini dapat dideskripsikan secara singkat dibawah ini. Setiap personal komputer mempunyai bagian penting seperti CPU, monitor, keyboard, mouse, dan printer. CPU merupakan induk dari komputer dimana didalamnya terdapat motherboard, memory, harddisk, dan prosesor. Motherboard merupakan piranti komputer yang terintgrasi. Monitor adalah perangkat yang digunakan untuk melihat hasil keluaran pekerjaan. Sedangkan keyboard dan mouse adalah piranti untuk menginput data. Sistem komputer terdiri atas hardware, software, dan brainware (manusia). Hardware adalah perangkat keras komputer yang terdiri bagian seperti disebutkan di atas, software adalah program yang mendukung operasional bekerjanya hardware. Sementara itu.. brainware adalah pengguna yang menggunakan perangkat komputer (hardware dan software).

A. Memahami Komponen Perangkat Keras Komputer

Perangkat keras adalah alat/perangkat yang dapat dilihat atau diraba secara langsung. Secara konseptual perangkat keras komputer terdir atas :

1. ALU yang berfungsi untuk melakukan perhitungan

2. CU berfungsi untuk mengendalikan pengolahan instruksi

3. Interface berfungsi untuk memindahkan instruksi dan data diantara CPU dan perangkat lainnya.

Beberapa jenis port yang terdapat pada komputer yaitu:

1. Port PS/2

2. Port Serial (Com1 dan Com2)

3. Port Paralel (LPT1, LPT2)

4. Port USB

5. Port VGA

6. Port Audio dan Microphone

7. Port Jarningan atau Ethernet Port

8. Port SCSI

9. Port IEEE

B. Meangaktifkan dan Mematikan Komputer Seusai Prosedur

Guna menjaga keselamatan kondisi fisik komputer dan mencegah kerusakan maka perlu berhati-hati dalam menghidupkan dan mematikan komputer.

Prosedur menghidupkan komputer yaitu dengan cara : 
1. Prosedur cold booting

Cold booting merupakan proses menghidupkan computer yang dimulai dari komputer dari keadaan mati atau off.

2. Prosedur warm booting adalah proses mengaktifkan computer yang dilaksanakan pada saat computer sedang dijalankan atau sedang aktif. Prosedur ini meliputi:

a. Melalui tombol start pada desktop

b. Melalui keyboard

Prosedur mematikan komputer secara umum sebaiknya dilakukan dengan melakukan shutting down melalui program windows.

Dampak mematikan komputer tidak sesuai prosedur biasanya harddisk akan kaget dan data dapat korup sehingga harus dilakukan instal ulang.

C. Mengenal Perangkat Lunak Komputer Perangkat lunak komputer merupakan perangkat yang berhubungan langsung dengan perangkat keras komputer. Beberapa jenis perangkat lunak komputer yaitu:

1. Perangkat lunak Sistem Operasi

Perangkat lunak ini berfungsi untuk mengaktifkan seluruh perangkat yang ada dalam sistem komputer (sumber daya komputer) sehingga dapat digunakan dengan optimal.

2. Perangkat lunak Aplikasi

Perangkat lunak aplikasi merupakan suatu perangkat lunak yang secara khusus diciptakan untuk kebutuhan dan fungsi tertentu beberapa contohnya seperti
a. Program aplikasi pengolah kata, table, dan basis data
b. Program aplikasi multimedia dan internet
c. Program aplikasi desain grafis
d. Program aplikasi antivirus

3. Perangkat lunak Pemrograman

Perangkat lunak pemrograman merupakan program yang digunakan untuk menciptakan sebuah program tertentu melalui sebuah bahasa pemrograman. Beberapa jenis kategori bahasa pemrograman yaitu:

a. Bahasa mesin

Bahasa mesin merupakan bahasa pemrograman generasi pertama dan bertipe paling dasar dari bahasa pemrograman yang mana hanya terdiri dari kumpulan angka-angka yang hanya dimengerti oleh mesin saja.

b. Bahasa assembly

Bahasa assembly merupakan bahasa generai kedua yang sedikit lebih mudah untuk dimengerti oleh manusia namun masih berbasis mesin.

c. Bahasa tingkat tinggi

Bahasa ini merupakan bahasa yang sepenuhnya telah berbasis bahasa manusia sehingga lebih mudah dalam menuliskan kode programnya.

Tahap selanjutnya dari kegiatan ini adalah mendemonstrasikan cara menginstalasi Windows. Langkahnya yaitu:

- Masukkan DVD windows atau colokkan flashdisk windows kita, dan kemudian booting lah memakai media yang telah kita pilih, lalu proses loading file akan dimulai.

- $\quad$ Pilih bahasa Kita, waktu \& format mata uang, keyboard atau metode input dan klik Next.

- Klik Install now

- $\quad$ Conteng I accept the license terms dan klik Next.

- Klik Upgrade jika Kita sudah mempunyai versi Windows sebelumnya atau Custom (advanced) jika kita tidak memiliki versi Windows sebelumnya atau ingin menginstal salinan baru Windows.

- (Lewati langkah ini jika Kita memilih Upgrade dan hanya memiliki satu partisi) Pilih drive mana Kita ingin 
menginstal Windows dan klik Next. Jika Kita ingin membuat partisi, klik opsi Drive options (advanced), buatlah partisi dan kemudian klik Next.

- Sekarang akan dimulai menginstal Windows 7. Langkah pertama, (yaitu Windows mulai menyalin file) sudah dilakukan ketika kita booting DVD/ fd Windows 7 sehingga akan selesai seketika.

- Setelah menyelesaikan langkah pertama, ia akan memperluas (decompress) file yang telah disalin.

- Langkah ketiga dan keempat juga akan diselesaikan langsung seperti langkah pertama.

- Setelah itu secara otomatis akan restart setelah 15 detik dan melanjutkan setup. Kita juga dapat klik Restart now untuk restart tanpa perlu menunggu.

- Setelah restart untuk pertama kalinya, proses setup akan dilanjutkan. Ini adalah langkah terakhir sehingga akan mengambil waktu yang agak lamadaripada langkah sebelumnya.

- Sekarang akan otomatis restart lagi dan melanjutkan setup. Kita dapat klik Restart now untuk restart tanpa perlu menunggu.

- Ketik nama pengguna yang Kita inginkan dalam kotak-teks dan klik Next. Nama komputer akan otomatis terisi.

- Jika Kita ingin mengatur sandi, ketik di kotak teks dan klik Next.

- Ketik kunci produk Kita dalam kotakteks dan klik Next. Kita juga dapat melewatkan langkah ini dan cukup klik Next jika Kita ingin mengetik kunci produk nanti. Windows akan berjalan hanya selama 30 hari jika Kita melakukan ini.

- $\quad$ Pilih opsi yang Kita inginkan untuk Windows Update.

- Pilih zona waktu dan klik Next.

- Jika kita terhubung ke jaringan apapun, ia akan meminta Kita untuk menetapkan lokasi jaringan.
Kegiatan PAKOM telah berlangsung selama 4 bulan. Beberapa target luaran yang telah dicapai diperlihatkan pada Tabel 4 berikut.

Table 4. Target luaran kegiatan

\begin{tabular}{|clll|}
\hline No & $\begin{array}{c}\text { Komponen } \\
\text { Luaran }\end{array}$ & Sebelum & Sesudah \\
\hline 1 & $\begin{array}{l}\text { Pengetahuan } \\
\text { TIK }\end{array}$ & Rendah & Meningkat \\
2 & $\begin{array}{l}\text { Ketrampilan } \\
\text { Komputer } \\
\text { dan aplikasi } \\
\text { perkantoran } \\
\text { Layanan } \\
\text { berbasis TIK }\end{array}$ & Terbatas & Ada \\
ketrampilan \\
\end{tabular}

Table 5. Target luaran terpublikasi

\begin{tabular}{|c|c|c|}
\hline No & Komponen Luaran & Publikasi \\
\hline 1 & Modul pelatihan TIK & Buku panduan \\
\hline 2 & $\begin{array}{l}\text { Model-model kegiatan } \\
\text { pelatihan }\end{array}$ & Laporan \\
\hline 3 & $\begin{array}{l}\text { Modul pelatihan Sistem } \\
\text { Operasi WIndows }\end{array}$ & Buku panduan \\
\hline 4 & $\begin{array}{l}\text { Artikel laporan } \\
\text { kegiatan }\end{array}$ & $\begin{array}{l}\text { Dimuat dalam } \\
\text { jurnal pengabdian } \\
\text { ber ISSN/SIBN }\end{array}$ \\
\hline
\end{tabular}

Kegiatan ini tidak akan mungkin berhasil tanpa adanya keterkaitan dengan beberapa pihak lain. Dalam hal ini pihak Desa Tuban Kecamatan Gondangrejo Kabupaten Karanganyar sebagai pihak yang mempunyai wilayah di mana kegiatan pengabdian pada masyarakat ini hendak dilakukan, memberi dukungan dalam kegiatan ini dengan menyediakan tempat pelatihan. Selain itu di masa mendatang pihak Dinas Tenaga Kerja Kabupaten Karanganyar diharapkan akan dapat memberikan dukungan melalui program-program yang terkait dengan peningkatan ketrampilan masyarakat golongan usia produktif.

Sementara itu dari sisi kelayakan pelaksana kegiatan, Ketua dan anggotaanggota tim pengusul kegiatan PAKOM ini telah mempunyai pengalaman yang cukup baik secara keilmuan maupun praktis di 
lapangan. Ketua peneliti mempunyai keahlian dibidang jaringan dan rancang bangun TI telah terbiasa mengampu baik praktek ataupun klasikal mata kuliah yang terkait dengan sistem komputer sehingga tidak akan ada kendala teknis dalam pelaksanaan kegiatan PAKOM ini. Selain itu, ketua peneliti berdomisili disekitar lokasi mitra dan telah mengenal mitra-mitra tersebut dengan baik sehingga pelaksanaan kegiatan PAKOM ini akan dapat berjalan lancar dan mendapat sambutan yang hangat dari para mitra. Demikian pula halnya dengan para anggota tim pengusul. Salah satu anggota mempunyai keahlian pula dibidang sistem komputer dan hardware. Adanya para tenaga pelaksana yang demikian itu maka dapatlah dijadikan andalan dalam pelaksanaan kegiatan PAKOM sampai tuntas.

Komitmen LPPM UMS sangatlah tinggi dalam mengembangkan potensi masyarakat baik dalam dunia pendidikan maupun bidang-bidang lainnya. Hal ini dapat dilihat dantaranya dengan banyaknya dibentuk pusat-pusat studi dan kajian dalam beragam cabang keilmuan. Semua pusat layanan dan kajian didukung oleh sumber daya manusia yang sangat memadai serta pendanaan yang mencukupi. Oleh karenanya dapat disampaikan bahwa dukungan LPPM UMS pada program-program pakom sangatlah memadai.

\section{KESIMPULAN}

Pelaksanaan kegiatan pengabdian ini telah memberikan beberapa hasil yang dapat disimpulkan sebagai berikut. Pertama, kegiatan pengabdian yang dilaksanakan disambut positif oleh warga khususnya perangkat desa di Desa Tuban dengan indikasi jumlah kehadiran peserta pelatihan rata-rata setiap tatap muka di atas lima orang. Kedua, pelaksanaan kegiatan pengabdian telah dapat diselesaikan dengan baik dan lancar dengan indikasi kegiatan dapat terlaksana sesuai dengan jadwal yang telah direncanakan dan ditetapkan sebelumnya. Ketiga, maksud dan tujuan kegiatan pengabdian telah dapat terpenuhi sesuai target yaitu sekitar $80 \%$ perserta pelatihan mempu menguasai dengan baik seluruh materi yang telah disampaikan pada saat pelatihan. Keempat, keterbatasan jumlah alat peraga yaitu perangkat komputer telah menjadi sedikit kendala dalam pelaksanaan sehingga capaian yang diharapkan dari kegiatan ini tidak dapat maksimal.

\section{DAFTAR PUSTAKA}

Ellis, G.F.R. 1999. The Dimension of Poverty dalam Social Indicator Research

Esmara, H. 2005. Perencanaan dan Pembangunan di Indonesia, Jakarta: Gramedia

Kempton, J. 2009. Human Resource Management and Development. London:MacMillan Press Ltd

Moeljanto, T. 2008. Pembangunan, Dilema dan Tantangan. Yogyakarta: Pustaka Pelajar

Nutt, G. 2000. Operating Systems, A Modern Perspective, $2^{\text {nd }}$ edition, Addison-Wesley.

NN. 2013. Demografi Desa Tuban, Kabupaten Karanganyar.

Solomon, D.A. \& Russinovitch, M.E. 2000. Inside Windows 2000, 3rd edition, MicroSoft Press.

Stallings, W. 2001. Operating Systems, Internals \& Design Principles, 4th edition, PrenticeHall. 